\title{
Entrepreneurial Development as a Panacea to Graduate Unemployment in Nigeria
}

\author{
Carl Madawa Seiyaibo \\ Department of Accountancy, Nnamdi Azikiwe University, Awka, Nigeria \\ Email: seiyaibocarl@gmail.com
}

How to cite this paper: Seiyaibo, C. M. (2020). Entrepreneurial Development as a Panacea to Graduate Unemployment in Nigeria. Open Journal of Business and Management, 8, 1854-1869.

https://doi.org/10.4236/ojbm.2020.84113

Received: February 10, 2020

Accepted: July 27, 2020

Published: July 30, 2020

Copyright $\odot 2020$ by author(s) and Scientific Research Publishing Inc. This work is licensed under the Creative Commons Attribution International License (CC BY 4.0).

http://creativecommons.org/licenses/by/4.0/

(c) (i) Open Access

\begin{abstract}
This study empirically examines the concept of Entrepreneurial Development as a panacea to graduate unemployment in Nigeria, adopting the multi-stage sampling technique; primary data were obtained from 360 respondents comprising lecturers and students of Niger Delta University Amassoma, Bayelsa State Nigeria, by means of structured questionnaires. Data reliability, testing and analysis were conducted using Cronbach's Alpha and Chi-square statistical tools respectively, The study revealed a positive and significant relationship between the development of adequate entrepreneurship curricula in Nigeria tertiary institutions and the production of innovative entrepreneurs, equally, the study suggests that the teaching of entrepreneurship courses in tertiary institutions is positively correlated with the development of self-sufficient graduates who possess employability attributes which invariably culminates in overall economic development. Thus, it is recommended that government in conjunction with the management of tertiary institutions should fashion out sustainable policies and programmes to inculcate and promote entrepreneurship education into the consciousness of the teeming undergraduates.
\end{abstract}

\section{Keywords}

Impact, Globalisation, Entrepreneurial, Development, Tertiary Institutions

\section{Introduction}

Over the years Nigeria has experienced an upsurge in graduate unemployment occasioned by the economic recession witnessed between 2017 to the second quarter of 2018, the economic downtown triggered several corporate collapses and the few surviving firms resorted to massive job cuts and downsizing which inevitably threw several youths into the labour market. Although graduate un- 
employment has become a global scourge, its adverse economic impact is more felt in developing economies like Nigeria with a huge young population within the working age bracket of 16 - 45 who can't seem to find gainful employment to eke out a respectable livelihood (Amuseghan \& Tayo, 2009). Data from the Enhancing Student Employability Co-ordination Team (ESECT) as espoused by Cranmer (2006), indicated that the global economic depression substantially impacted negatively on graduate employability. Higher institutions found themselves under pressure and intense competition to produce graduates who can think outside the box and create jobs; hence there was the need to focus on instilling hands-on practical job skills into their students that will make them job creators rather than job seekers. In the same vein industries and governments have continued to lend their voices to the philosophy that the undergraduate curricula should be completely overhauled to incorporate the development of hand-on practical skills and innovative capacity relevant to creating solutions to societal problems (OECD, 2001; Papayannakis, Kastelli, Damigos, \& Mavrotas, 2008). Employers of labour are in dire need of graduates with enterprising skills-sets and creative capacity to innovate, network and effectively manage relationships. Moreland (2007) and Amuseghan and Tayo (2009) also averred that the astronomical rise in the unemployment rate amongst Nigerian graduates is as a result of the defective curricula of the universities and other tertiary institutions focused on training for white-collar jobs. In a bid to correct this anomaly, the Federal Government of Nigeria in conjunction with the Ministry of Commerce, Industry and Investment inaugurated a programme tagged "University Entrepreneurship Development Programme" (UNEDEP) whose objective was basically to promote self-employment among the youth right from the institutions of higher learning (Olusegun, 2013). It also had the support of the Federal Ministry of Education and the Small and Medium Enterprise Development Agency (SMEDAN) in the implementation of the UNEDEP project to enhance and re-orientate the values of undergraduates, and provide a mentoring platform for students and reducing poverty and youth unemployment (Olusegun, 2013).

Furthermore, globalization has negatively affected the graduates of tertiary institutions in different countries as evidenced by the competitive demand of expertise workforce and result-oriented graduates in either taking up appointment or setting up a business. According to Norasmah, Harinder, Poo, and Noorasiah (2012), globalization challenged higher educational institutions to undergo revolutionary changes to ensure that human capital is "produced" not for a product-based economy, but for knowledge-based economy (Norasmah et al., 2012), consequent upon the foregoing. Several contending factors have been observed to have constrained Nigerian tertiary institutions in developing entrepreneurial capacity of global competitiveness in their graduates. Accordingly, the outcome of this inability has resulted in:

1) Many Nigerian graduates' roaming the streets without employable skills-sets.

2) Many Nigerian higher institutions that have entrepreneurship as a course 
are theoretically taught, having the output to be product-based without hands-on practical instructions.

3) Inability to develop result oriented entrepreneurial curricula in Nigerian tertiary institutions that meets global standards.

4) There exist a disconnect between industry expectations of graduates and the training instilled at higher institutions in terms of practical training of undergraduates on entrepreneurship, however this does not ignore the efforts of tertiary institutions on students' compulsory industrial training (SIWES) placement in firms and corporate organizations, without a genuine recourse to knowledge acquisition, but fulfilment of academic demands.

Following the introduction, Section two (2) addresses the conceptual framework of Entrepreneurial development in Nigeria. In Section three (3) the research methodology and design are discussed, while in Section four (4) a detailed presentation of analysis of elicited responses is utilised to test the formulated hypotheses and in Section five (5) the research findings are discussed are recommendations suggested.

\section{Literature Review and Conceptual Framework}

\subsection{Entrepreneurship}

The term Entrepreneur has its origins in the French root word "entreprendre". The German called it "unternehmen" which means undertake (Afonja, 1999). A common definition by the Oxford Dictionary of an entrepreneur is someone who undertakes the responsibility of organisation or task managing it and assumes responsibilities of all associated risks that relates to the task. The early $18^{\text {th }}$ century French economist Richard Cantillon (1755) introduced the term entrepreneurship and have it defined as agent who by through production activities at a given prevailing price convert input to a new product. Entrepreneurship acts as an agent for self-employment of any sort; hence the entrepreneur is the risk bearer.

The Entrepreneur is an agent of economic growth in the society, to understand the attitudes and motivations in entrepreneurship, a survey conducted by Amway Global Entrepreneurship Report [AGER] (2013) covering 2006 respondents in 24 countries, indicated that entrepreneurship possesses a continued high reputation as $70 \%$ of the respondents demonstrated a positive attitude towards entrepreneurial involvement, while $39 \%$ dreamt of becoming self-employed. Yet, the gap between potential entrepreneurs-people that have a latent preparedness to embrace an entrepreneurial opportunity-an actual entrepreneur is still large (AGER, 2013). Entrepreneurship acts as an impetus to economic growth. Entrepreneurs identify an opportunity or new idea and develop it into a new venture or project (Davidson, 2004). Entrepreneurship is a risk oriented and tasking job that requires knowledge, skills and intuition to perform its duties. Entrepreneur through its activities generates value, in the form of financial, social or emotional outcome in considering academic history of entrepreneurship, 
intellectuals and scientists cutting across various fields of studies such as management (Stevenson, 1985), anthropology (Stewart, 1991), sociology (Reynolds, 1991), psychology (Shaver \& Scott, 1991), technology (Roberts, 1991), economics (Kirchhoff, 1991) and (Litvak \& Maule, 1999) have come to grips with a varied set of clarifications and meaning to theorise this non-representational idea.

\subsection{Efforts of Nigeria Government in Entrepreneurial Development}

The role played by government in entrepreneurial development in Nigeria gained prominence only after the Nigeria civil war (1967-70). Since the mid-1980s government has exhibited increased commitment to entrepreneurship development, immediately after the launch of the structural adjustment economic program (SAP) in 1986, a further reassessment of the value of entrepreneurship necessitated the establishment of the National Directorate of Employment (NDE), National Open Apprenticeship Scheme (NOAS), Small and Medium Enterprise Development Association of Nigeria (SMEDAN, SMEEIS, etc.) (Lawal, 2013).

These government interventions assisted in promoting entrepreneurial culture amongst the citizenry and equally cultivated positive entrepreneurial character traits of confidence, positive attitude, pride in success, innovativeness and the promotion of research and development (R\&D), which resulted in cheap access to financial resources, enabled unhindered access to market, prompt registration/advisory services to businesses, entrepreneurial skills acquisition development reform through education and manpower development. In furtherance government stepped-up infrastructural development and made available export incentives by creating stable macro-economic environment that encourage security of investment, by ensuring a stable political climate (Lawal, 2013).

Entrepreneurship studies were adopted in the Nigerian higher institutions as a mandatory course and also its inclusion in the educational curriculum, with Centres for Entrepreneurship Development (CED) established in all tertiary institutions operating in the country. With objectives to make graduates employable and provide job opportunities for others and enhance wealth generation (Fadeyibi \& Chaudhuri, 2014). United Nations Educational, Scientific and Cultural Organisation-Technical and Vocational Education (UNESCO-TVE) programs in Nigeria also foster solid linkage and possible cooperation between higher institutions and industries. In order to create enabling environment that will encourage academic research with expected results of products development and increased production (Eshiobo, 2012).

\subsection{Tertiary Institutions in Development of Entrepreneurship Capabilities}

The rapidly changing environment has brought about new teaching and research conditions for higher education. The outcome of these situations necessitated 
the development of entrepreneurial capabilities in the world in order to create new business, take advantage of university tapped capacities to develop existing capacities and solved social problems. In response to these challenges, the new mission of universities should be to inculcate new entrepreneurial capabilities in universities' graduates, to this end; universities should be ready and prepared to create a noble path towards satisfying industry expectations. Academic entrepreneurship is about solving scientific problems of the society, government and firms; supplying the results of academic researches to the industry; producing and supplying new technologies and innovation in expanding the frontiers of human knowledge (Hasoumi \& Abtahi, 2006).

The relevance of entrepreneurship to the economic system necessitated the introduction of entrepreneurship education in tertiary institutions. Entrepreneurship been the process of innovation in economic organizations assisted in the introduction of new products and diversified market (Zubaidah \& Rugayah, 2008). Entrepreneurship education extensively contributed to the factor of human capital quality development. Entrepreneurship training, embodied the assemblage of relevant courses and programs which are implemented by educational and government institution (Othman, Othman, \& Ismail, 2012). The efforts to establish such training began in the 1980's with increases in the offerings of entrepreneurship courses and programs, especially in some developed countries, such as the United States and European countries (Norasmah, Ahmad, Mohd, \& Ariffin, 2008). Introduction of any entrepreneurship developmental policy for tertiary institutions is to encourage the development of human capital and enabling graduates to possess the attributes and values of entrepreneurship (Prepelita-Raileanu \& Pastae, 2010).

Entrepreneurs performed the role of change agents, as they integrate various factors of production to provide something new and novel to the community by means of their innovative and creative ideas (Pinki, 2013). The continual transmission of entrepreneurship development benefit is a greater task that has successive government in knowledge, skill, behaviour and attitudinal development of persons to assume the role of entrepreneur (Osemeke, 2012). Entrepreneurs production transformation embodied the ability to identify business opportunities and harness the necessary resources in utilising the opportunities identified.

According to Paul (2005), entrepreneurship education is structured to achieve the following objectives:

1) A functional education that brings about youth self-employment and self-reliance.

2) Provide the youth graduates with adequate capacity and equips youth graduates to be creative, innovative, and capable of identifying novel business opportunities.

3) Entrepreneurship education acts as a catalyst for economic growth and development.

4) It also empowered graduates with the requisite skills in risk management, 
and employment generation, which create results in rural-urban drift.

5) Through entrepreneurship education, university graduates are able to pursue a career in small and medium scale business.

\section{Research Methodology}

\subsection{Research Design}

The study adopted the survey design descriptive technique and primary data were obtained through respondents from questionnaires. In order to identify the key issues influencing entrepreneurship development, a structured questionnaire was used to gather primary data. It was designed to capture and identify determinants of competitive entrepreneurial development parameters in tertiary institutions of Nigeria. The eight questions are grouped into four main questions. Every two questions X-ray a particular variable. Question 1 and 2 addressed curricula adequacy. While, question 3 and 4 focused on employability of graduates competitively. Entrepreneurship courses are examined in question 5 and 6 and finally, question 7 and 8 concentrated on quality of entrepreneurship education in Nigeria.

\subsection{Population and Sample Size of the Research}

The target population of the study is the entire Nigerian tertiary education sector. The sample size was 360 respondents from lecturers and students of Niger Delta University Amassoma, Bayelsa State Nigeria, the multi-stage sampling technique was employed in data collection at stage one, the ten faculties in the university are classified. While, at stage two the number of respondents was established from each department within each cluster. At stage three, the different independent variables were despondently grouped. The reason for this categorization was to enable equal representation of all department accredited by Nigerian Universities Commission [NUC] in the school in order to examine the variables proposed in testing the hypotheses.

\subsection{Reliability}

Reliability dictates how accurately and precisely the measurement is made on a certain variable by a research instrument. The lower the error, the higher is the reliability of the instrument. Cronbach's Alpha is a reliability measure.

Cronbach's alpha,

$$
\alpha=\frac{k\left[1-\left(\sum s i^{2} / s t^{2}\right)\right]}{K-1}
$$

$k=$ number of items in the questionnaire

$s i^{2}=$ overall variance of the questionnaire

$s t^{2}=$ variance for 1 st item in the questionnaire

The Cronbach's alpha measurement tool is employed in determining data reliability. Hence, an alpha of (7) and above is approved better and reliable applied 
data. Consequent upon the foregoing, and referenced to appendix 7, reliability is confirmed to be 7.85 . This is above the benchmarked 7.0 and acceptable internal consistency test.

\subsection{Techniques for Data Analysis}

The data obtained was analysed through simple percentage. The percentage is a representation of the number of respondents who subscribed to a particular thought or view, i.e. Yes or No. The number of questionnaires completed and returned by the respondents represents $100 \%$, while the number of positive or negative responses represents a fraction of $100 \%$. The chi-square statistical model was used in testing the hypotheses of the research with a 5\% level of significance been considered appropriate. In analysing the data, the Minitab 18 was used. The application of the test tool is based on its usefulness in determining the correlation of the testable variables.

\subsection{Statement of Research Hypotheses}

In order to effectively address the objectives of this study the following hypotheses are formulated in the null form:

$H_{01}$-There is no significant relationship between developing adequate entrepreneurship curricula in Nigeria tertiary institutions and producing innovative entrepreneurs by tertiary institutions.

$\mathrm{H}_{02}$ - There is no significant relationship between the teaching of entrepreneurship courses in tertiary institutions and the graduation of self-sufficient graduates.

$H_{03}-$ Employability of graduates has no relationship with entrepreneurial development in tertiary institutions in Nigeria.

$H_{04}$-There is no significant relationship between the quality of entrepreneurship education in Nigeria and improvement of the economy.

In line with the Topic of this paper, Entrepreneurial Development skill is key to solving the challenge of graduate unemployment in Nigeria, which will go a long way in improving overall economic growth and development. But for this to be achieved Tertiary Institutions are the key drivers. In the process of research, development and training of these undergraduate to ensure that employability skills are inculcated. In these wise hypotheses 1, 2 and 3 address the role Tertiary Institutions play in the development of Entrepreneurship Curricula and training to produce self-sufficient graduates, while Hypothesis 4 addresses the impact of Entrepreneurial education on overall economic growth and development.

\section{Presentation and Analysis of Responses and Hypotheses Testing}

Out of the 359 respondents, 198 of them, which is $55.15 \%$ of them responded YES, while, the remaining 161 respondents which constitutes $44.85 \%$ of the responses. 
From the result in Table 1, it could be deduced that $55.15 \%$ of respondents said that relationship exists in the development of adequate entrepreneurship curricula in Nigeria tertiary institution and the production of innovative entrepreneurs by tertiary institutions. While, $44.85 \%$ disagreed and stated that no correlation exists.

Out of the 359 respondents, 198 of them, which are $55.15 \%$ of them responded YES, while, the remaining 161 respondents which constitutes $44.85 \%$ of the responses said no.

The computation in Table 2 shows that those who agreed on the existence of a relationship in teaching entrepreneurship courses and graduation of self-sufficient graduate are of high percentage than those signifying that entrepreneurship courses being offered has nothing to do with graduating self-sufficient students.

The analysis in Table 3 indicates that $61.00 \%$ said Yes, implying that competitive employability of students worldwide has to do with skilful entrepreneurial development in the life of student in the tertiary institution. While, 39.00\% disagreed of the above preposition and states that employability of graduates has nothing to do with entrepreneurship education.

Table 4 shows that, $55.18 \%$ of the analyzed data said yes, indicating that quality of entrepreneurship education improves the Nigerian economy. The remaining $44.82 \%$ said No, disagreeing on the insinuation that quality of entrepreneurship improves the economy.

\section{Hypothesis One:}

$H_{01}$ - There is no significant relationship between developing adequate entrepreneurship curricula in Nigeria tertiary institutions and producing innovative entrepreneurs by tertiary institutions.

Table 1. Correlation between developing adequate entrepreneurship curricula in Nigeria tertiary institutions and producing innovative entrepreneurs by tertiary institutions.

\begin{tabular}{cccccc}
\hline S/No & Response & Students & Lecturers & Total & $\%$ \\
\hline 1 & Yes & 188 & 10 & 198 & 55.15 \\
2 & No & 144 & 17 & 161 & 44.85 \\
& & 332 & 27 & 359 & 100 \\
\hline
\end{tabular}

Source: Fieldwork, 2020.

Table 2. Relationship exists in teaching entrepreneurship courses in tertiary institutions cause the graduation of self-sufficient graduates.

\begin{tabular}{cccccc}
\hline S/No & Response & Students & Lecturers & Total & $\%$ \\
\hline 1 & Yes & 181 & 23 & 204 & 57.95 \\
2 & No & 143 & 5 & 148 & 42.05 \\
& & 324 & 28 & 352 & 100 \\
\hline
\end{tabular}

Source: Fieldwork, 2020. 
Table 3. Effect on the employability of Nigeria graduates competitively worldwide and entrepreneurial development in tertiary institutions in Nigeria.

\begin{tabular}{cccccc}
\hline S/No & Response & Students & Lecturers & Total & $\%$ \\
\hline 1 & Yes & 210 & 9 & 219 & 61.00 \\
2 & No & 123 & 17 & 140 & 39.00 \\
& & 333 & 26 & 359 & 100 \\
\hline
\end{tabular}

Source: Fieldwork, 2020.

Table 4. Relationship on quality of entrepreneurship education in Nigeria and improvement of the economy.

\begin{tabular}{cccccc}
\hline S/No & Response & Students & Lecturers & Total & $\%$ \\
\hline 1 & Yes & 190 & 7 & 197 & 55.18 \\
2 & No & 138 & 22 & 160 & 44.82 \\
& & 328 & 29 & 357 & 100 \\
\hline
\end{tabular}

Source: Fieldwork, 2020.

Table 5 indicated that $\mathrm{N}=359, \mathrm{Df}=3$, Chi-Sq. $=270.181$ and $P$-value $=0.000$. Because the $p$-value is less than the significance level of 0.05 , the researcher accepts the alternate hypothesis which states that there is a correlation between developing adequate entrepreneurship curricula in Nigeria tertiary institutions and producing innovative entrepreneurs by tertiary institutions (see Figure 1).

\section{Hypothesis Two:}

$H_{02}$-There is no significant relationship between the teaching of entrepreneurship courses in tertiary institutions and the graduation of self-sufficient graduates.

Table 6, revealed that $\mathrm{N}=352, \mathrm{Df}=3$, Chi-Sq. $=258.955$ and $P$-value $=0.000$. Because the $p$-value is less than the significance level of 0.05 , the researcher accepts the alternate hypothesis which states that a relationship exists in teaching of entrepreneurship courses in tertiary institutions and the graduation of self-sufficient graduates (see Figure 2).

\section{Hypothesis Three:}

$H_{03}$-Employability of graduates has no relationship with entrepreneurial development in tertiary institutions in Nigeria.

Table 7 indicates that $\mathrm{N}=359, \mathrm{Df}=3$, Chi-Sq. $=305.056$ and $P$-value $=0.000$. Because the $p$-value is less than the significance level of 0.05 , the researcher accepts the alternate hypothesis which states that relationship exists between employability and entrepreneurial development in tertiary institutions in Nigeria (see Figure 3).

\section{Hypothesis Four:}

$\mathrm{H}_{04}$ There is no significant relationship between the quality of entrepreneurship education in Nigeria and improvement of the economy.

Table 8 reveals that $\mathrm{N}=357, \mathrm{Df}=3$, Chi-Sq. $=266.832$ and $P$-value $=0.000$. 
Table 5. Computation of chi-square $\left(\mathrm{X}^{2}\right)$ of response frequencies between developing adequate entrepreneurship curricula in Nigeria tertiary institutions and producing innovative entrepreneurs by tertiary institutions.

\begin{tabular}{ccccc}
\hline Category & Observed & Test Proportion & Expected & Contribution to Chi-Square \\
\hline A & 188 & 0.25 & 89.75 & 107.555 \\
B & 10 & 0.25 & 89.75 & 70.864 \\
C & 144 & 0.25 & 89.75 & 32.792 \\
D & 17 & 0.25 & 89.75 & 58.970 \\
\hline \multicolumn{5}{r}{} \\
\hline N & Chi-Square Test & $P$-Value \\
\hline 359 & DF & Chi-Sq. & 0.000 \\
\hline
\end{tabular}

Table 6. Computation of chi-square $\left(\mathrm{X}^{2}\right)$ of response frequencies between teaching of entrepreneurship courses in tertiary institutions and the graduation of self-sufficient graduates.

\begin{tabular}{ccccc}
\hline Category & Observed & Test Proportion & Expected & Contribution to Chi-Square \\
\hline A & 181 & 0.25 & 88 & 98.2841 \\
B & 23 & 0.25 & 88 & 48.0114 \\
C & 143 & 0.25 & 88 & 34.3750 \\
D & 5 & 0.25 & 88 & 78.2841 \\
\hline & \multicolumn{5}{r}{ Chi-Square Test } \\
\hline N & DF & Chi-Sq. & $P$-Value \\
\hline 352 & 3 & 258.955 & 0.000 \\
\hline
\end{tabular}

Table 7. Computation of chi-square $\left(\mathrm{X}^{2}\right)$ of response frequencies between employability and entrepreneurial development in tertiary institutions in Nigeria.

\begin{tabular}{ccccc}
\hline Category & Observed & Test Proportion & Expected & Contribution to Chi-Square \\
\hline A & 210 & 0.25 & 89.75 & 161.115 \\
B & 9 & 0.25 & 89.75 & 72.653 \\
C & 123 & 0.25 & 89.75 & 12.318 \\
D & 17 & 0.25 & 89.75 & 58.970 \\
\hline \multicolumn{5}{r}{ Chi-Square Test } \\
\hline N & Chi-Sq. & $P$-Value \\
\hline 359 & 3 & 305.056 & 0.000 \\
\hline
\end{tabular}

Because the $p$-value is less than the significance level of 0.05 , the researcher accepts the alternate hypothesis which states that a relationship exists between 
Table 8. Computation of chi-square $\left(\mathrm{X}^{2}\right)$ of response frequencies between quality of entrepreneurship education in Nigeria and improvement of the economy.

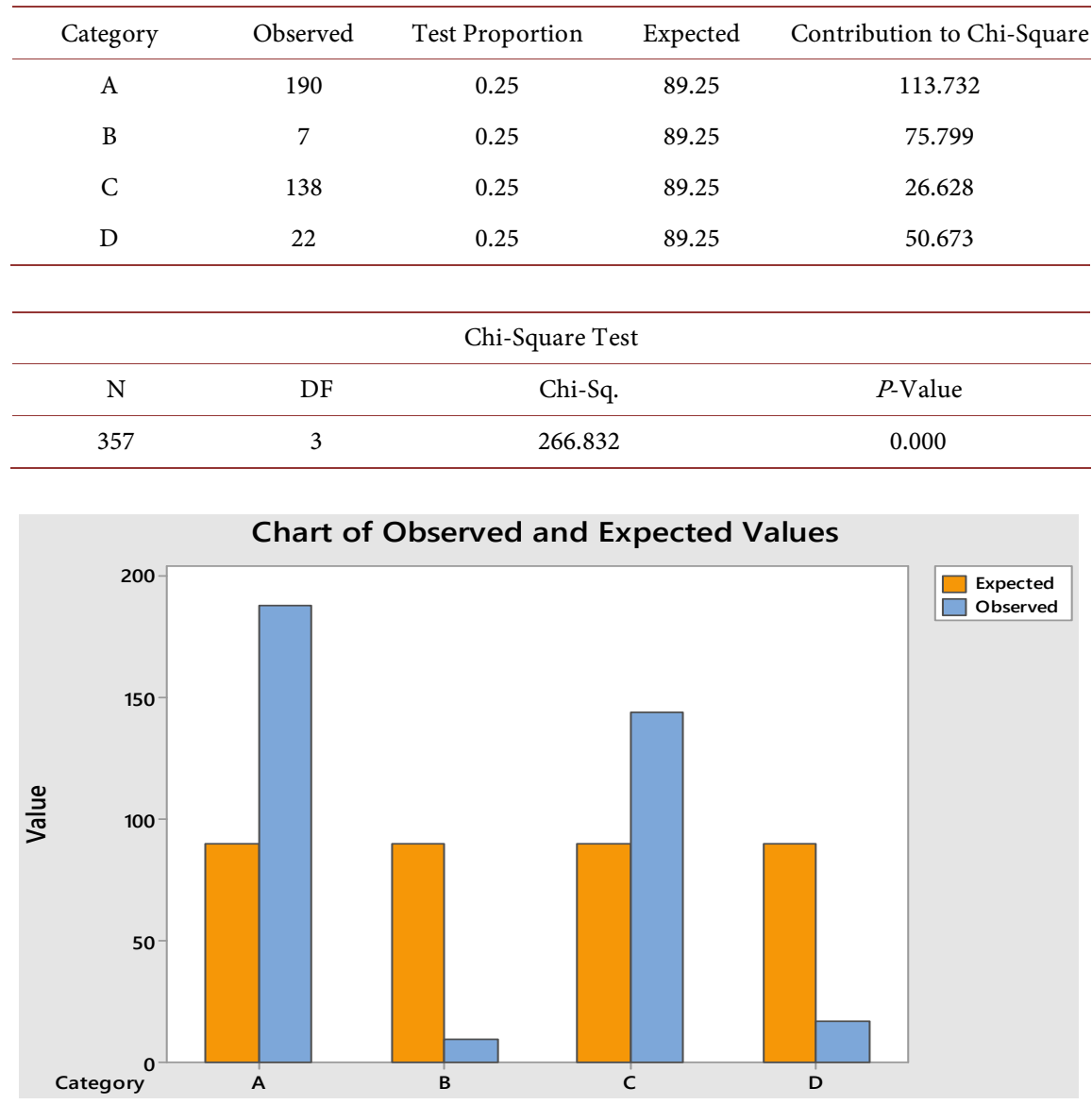

Figure 1. Observed and expected values for developing adequate entrepreneurship curricula in Nigeria tertiary institutions and producing innovative entrepreneurs by tertiary institutions.

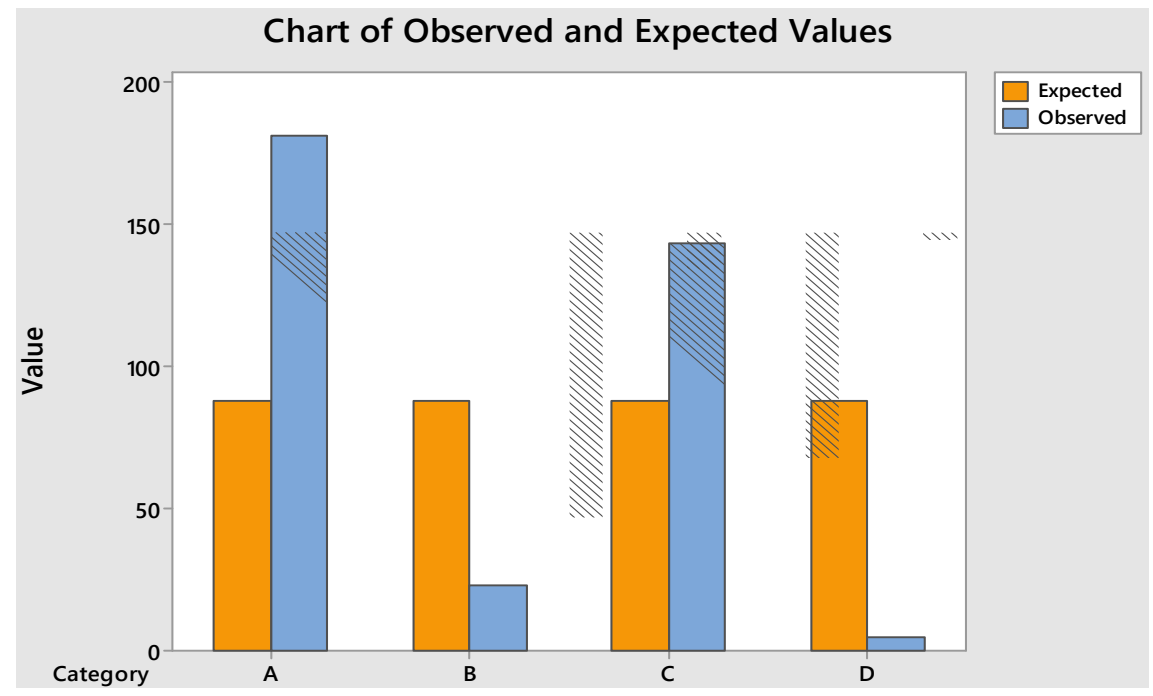

Figure 2. Observed and expected values for teaching of entrepreneurship courses in tertiary institutions and the graduation of self-sufficient graduates. 


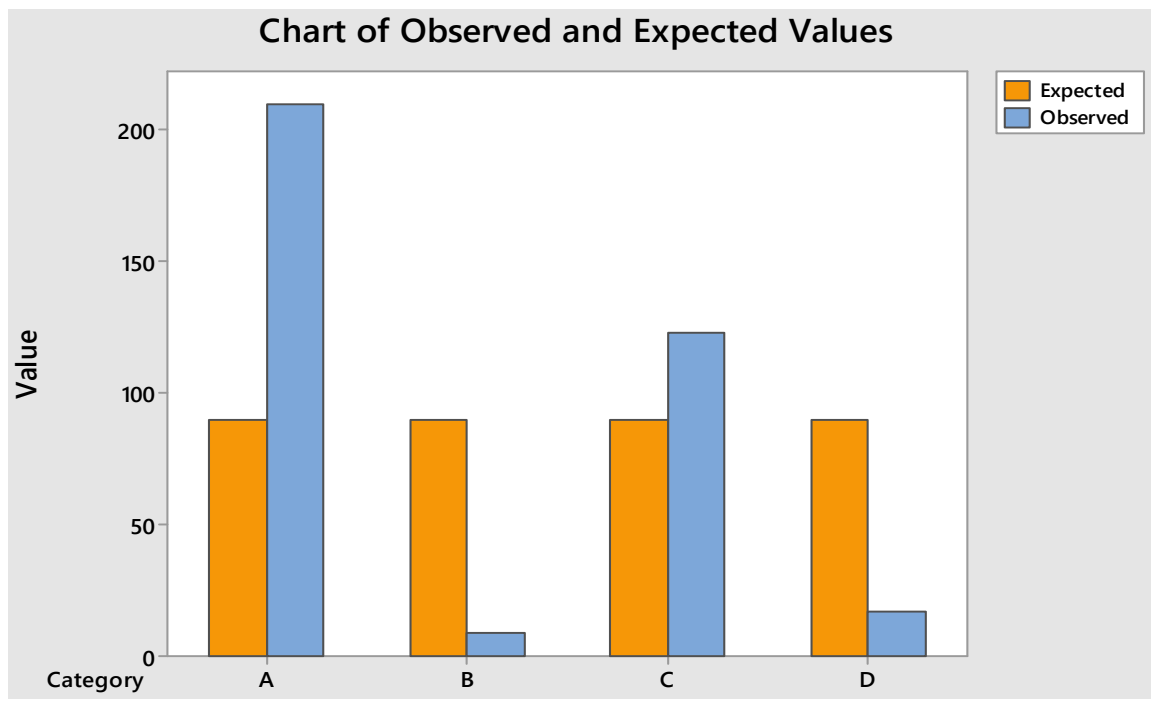

Figure 3. Observed and expected values for teaching of entrepreneurship courses in tertiary institutions and the graduation of self-sufficient graduates.

quality of entrepreneurship education in Nigeria and improvement of the economy (see Figure 4).

\section{Discussion of Findings}

The test of the first hypothesis on the impact of globalisation on entrepreneurial development offers a gainful insight on the significance of entrepreneurship curricula in Nigeria tertiary institutions and producing innovative entrepreneurs. The statistical test on the relationship between developing adequate entrepreneurship curricula in Nigeria tertiary institutions and producing innovative entrepreneurs by tertiary institutions indicated appositive and significant relationship, this result corroborates the studies of Okoye (2012) and Ololube et al. (2013), who opines that adequate curriculum development allows for a balanced development of the learners.

Hypothesis two revealed that a positive relationship exists between the teaching of entrepreneurship courses in tertiary institutions and the development of self-sufficient graduates. This finding further buttressed by works of Obanya (2014) which states that entrepreneurship education taught within the context of vocational and technical education assists in developing entrepreneurial spirit which stimulates creative outputs.

Hypothesis three revealed a positive relationship between employability and entrepreneurial development in tertiary institutions in Nigeria, this finding corroborates Akanmu (2011), who posits that employers expects graduate recruits to be technically competent in their chosen field. Tertiary institutions are expected graduate student with complementary problem solving skills and capacity for critical thinking in the same vein, Steven \& Fallows (1998), and Adeyemo, Ogunleye, Adenlwye, and Adenle (2010), state that to produce self-sufficient graduates, there should be a synergy between what the industry requires and 


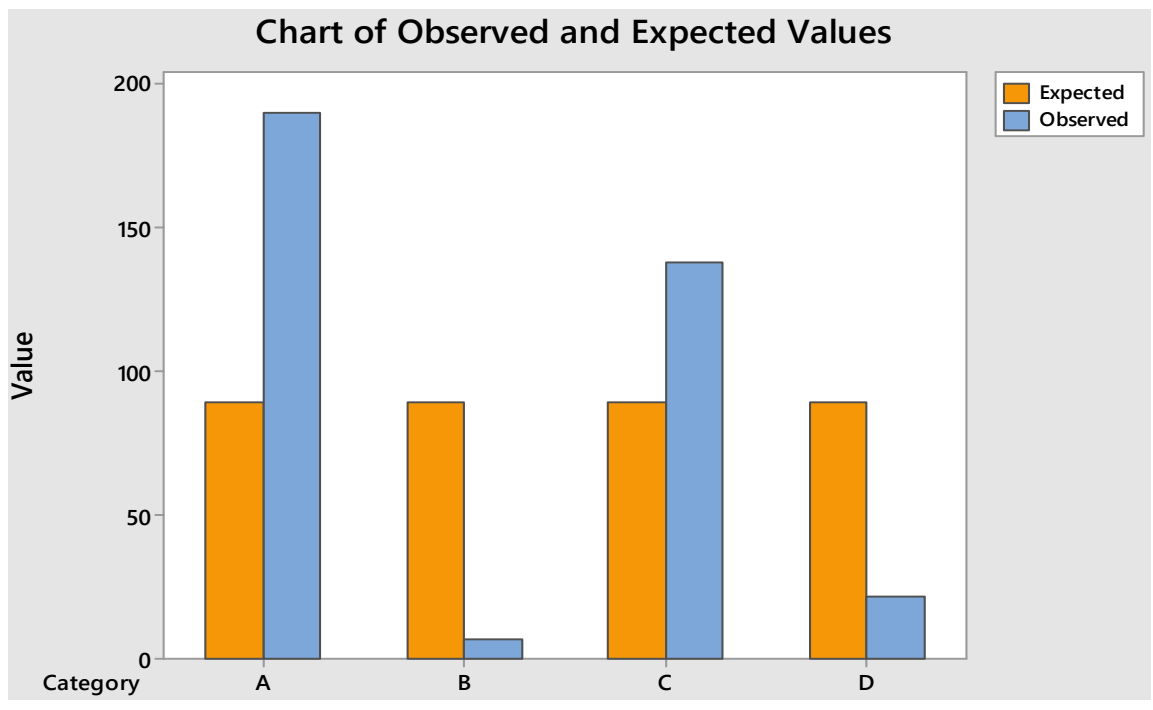

Figure 4. Observed and expected values relationship exists between quality of entrepreneurship education in Nigeria and improvement of the economy.

what tertiary institutions are teaching hence the inclusion of employability content in the higher education curriculum to provide formal life skills training for students.

Finally, the study revealed a positive relationship between quality of entrepreneurship education in Nigeria and economic development. Notably, quality entrepreneurship education plays a vital role in the social, political and economic development of any nation. It becomes imperative to equip citizens with entrepreneurial skills so they can create jobs by establishing a lot of business outfits as every qualified graduate of entrepreneurship education is expected to have the requisite skills relevant to manage small business concerns (Olorumolu \& Agbede, 2012; Osuala, 2012).

\section{Conclusion}

Conclusively, any nation that abandons or treats entrepreneurship education with levity undermines rapid and transformational development; hence if Nigeria seriously intends to tackle the scourge of unemployment and technologically backwardness, it is recommended that relevant stakeholders; authorities of the government, management of tertiary institutions should fashion sustainable measures to inculcate entrepreneurship education amongst the teeming undergraduates. The establishment of Centres of Entrepreneurial Studies (CES) in tertiary institutions across the country is a step in the right direction.

Furthermore, this study is not exhaustive as regards entrepreneurial development in Nigeria as future research on the subject matter can focus on:

1) Measuring the Economic Contribution of Entrepreneurial Skill on Gross Domestic Product (GDP);

2) Appraising the Cost Benefits of Government Social Investment Programs on the Enhancement of Small Scale and Medium Enterprises in Nigeria; 
3) Relationship between Development of Entrepreneurial Skill and Crime Reduction in Nigeria.

\section{Conflicts of Interest}

The author declares no conflicts of interest regarding the publication of this paper.

\section{References}

Adeyemo, S. A., Ogunleye, A. O., Oke, C. O., \& Adenle, S. O. (2010). A Survey of Factors Determining the Employability of Science and Technology Graduates of Polytechnics and Universities in the Nigerian Labour Market. Journal of Science and Technology Education Research, 1(5), 99-105.

Afonja, A. A. (1999). Entrepreneurship Education and Enterprise Culture: Lessons from Other Countries. National Conference on Entrepreneurship Education in Nigeria Tertiary Institutions, Abuja, 30 March-1 April 1999.

Akanmu, O. (2011). Graduate Employment and Employability Challenges in Nigeria. Proceedings of the British Council Global Higher Education Conference, Hong Kong, 12 March 2011.

Amuseghan, S. A., \& Tayo-Olajubutu, O. (2009). Spinning off an Entrepreneurship Culture among Nigerian University Students: Prospects and Challenges. African Journal of Business Management, 3, 80-88.

Amway Global Entrepreneurship Report (2013). Encouraging Entrepreneurs-Eliminating the Fear of Failure (pp. 1-24). Puchheim: Amway GmbH.

Cranmer, S. (2006). Enhancing Graduate Employability: Best Intentions and Mixed Outcomes. Studies in Higher Education, 31, 169-184.

https://doi.org/10.1080/03075070600572041

Davidson, P. (2004). Researching Entrepreneurship. New York: Springer.

Enhancing Student Employability Co-ordination Team (2005). Enhancing Student Employability. Learning and Employability Series. York, England: Higher Education Academy.

Eshiobo, S. S. (2012). Entrepreneurship in Innovation, Phenomenal Growth of Enterprises and Industrial Organizations in Nigeria on en.wikipedia.org/wiki/entrepreneurship.

Fadeyibi, I. O., \& Chaudhuri, M. R. (2014). Edifying the Culture of Innovation in Entrepreneurship Development in Nigeria. Management Studies and Economic Systems (MSES), 1, 115-125. https://doi.org/10.12816/0006210

Hasoumi, T., \& Abtahi, M. (2006). Strategies for Developing Entrepreneurial Culture in University and Society. 1st Conference on Identification of Employment Capabilities, Barriers and Strategies, Mashhad.

Kirchhoff, B. (1991). Entrepreneurship and Dynamic Capitalism: The Economics of Business Firm Formation and Growth. Westport, CT: Praeger Press.

Lawal, A. B. (2013). Entrepreneurship and Innovation: Yard Stick for Growth of Enterprises and Industrial Organisations in Nigeria. The 7th National Conference of College of Administration and Management Studies, Hassan Usman Katsina Polytechnic, Katsina-Katsina State, 1-16.

Litvak, I. A., \& Maule, C. J. (1999). Comparative Technical Entrepreneurship: Some Perspectives. Journal of International Business Studies, 7, 31-38. 
Moreland, N. (2007). Entrepreneurship and Higher Education: An Employability Perspective. UK: The Higher Education Academy.

Norasmah, O., Ahmad, A. M. A., Mohd, F. M. J., \& Ariffin, Z. (2008). Entrepreneurial Studies in Higher Education: Methods for Delivering Entrepreneurship Education: In Y. B. A. Bakar, A. B. H. Mokhiar, R. B. J. Jan, A. M. B. Zubairi, N. B. D. Othman, \& A. Gan (Eds.), Enhancing the Quality of Higher Education through Research: Shaping Future Policy (pp. 115-135). Malaysia: The Ministry of Higher Education.

Norasmah, O., Harinder, K. T. S., Poo, B. T., \& Noorasiah, S. (2012). Globalization and the Trend in Demand for Higher Education in Malaysia. International Journal of Education and Information Technologies, 6, 131-140.

Obanya, P. (2014). Educationeering (pp. 1-704). Ibadan: Heinemann Educational Books Nigeria.

Okoye, M. E. (2012). Curriculum Development and Quality Assurance in Education. The 2012 International Conference of the Institute of Education, Delta State University, Abraka, 12-15 June 2012.

Ololube, N. P., Dudafa, U. J., Uriah, A., \& Agbor, C. N. (2013). Education for Development: Impediments to the Globalization of Higher Education in Nigeria. International Journal of Educational Foundations and Management, 1, 109-130.

Olorumolu, J. O., \& Agbede, E. A. (2012). Quality Entrepreneurship Education: A Panacea for Job Creation in Nigeria. Journal of Resourcefulness and Distinction, 1, 175-181.

Olusegun, A. (2013). Nigeria Launches New Self-Employment Scheme for Undergraduates. Premium Times, 21 May 2013.

Osemeke, M. (2012). Entrepreneurial Development and Interventionist Agencies in Nigeria. International Journal of Business and Social Science, 3, 255-265.

Osuala, E. C. (2012). Principles and Methods of Business and Computer Education. Enugu: Cheston Agency Ltd Pub.

Othman, N, Othman, N. H., \& Ismail, R (2012). Impact of Globalization on Trends in Entrepreneurship Education in Higher Education Institutions. International Journal of Trade, Economics and Finance, 3, 267-271. https://doi.org/10.7763/IJTEF.2012.V3.212

Papayannakis, L., Kastelli, I., Damigos, D., \& Mavrotas, G. (2008) Fostering Entrepreneurship Education in Engineering Curricula in Greece. Experiences and Challenges for a Technical University. European Journal of Engineering Education, 33, 199-210. https://doi.org/10.1080/03043790801980086

Paul, E. O. (2005). Entrepreneurship Education. In P. M. Ezema, D. E. Paul, B. O. Aniolie, G. A. G. Okwuolisa, I. A. Eheli, \& H. U. Anih (Eds.), Entrepreneurship in Vocational Education. Enugu: OZYBEL Publishers.

Pinki (2013). Entrepreneurship Development: Converting Dreams into Reality. Journal of Business Management \& Social Sciences Research (JBM\&SSR), 2, 93-98.

Prepelita-Raileanu, B., \& Pastae, O. M. (2010). Bridging the Gap between Higher Education, Academic Research and Romanian Business Community. Proceedings of the 9th WSEAS Conference on Education and Education Technology, Japan, 4-6 October 2010, 56-61.

Reynolds, P. (1991). Nascent Entrepreneurship in Northern Europe. In EIM (Ed.), Entrepreneurship in the Netherlands (pp. 528-554). The Hague/Zoetermer: EIM/EZ.

Roberts, E. B. (1991). Entrepreneurs in High Technology: Lessons from MIT and Beyond. New York: Oxford University Press.

Shaver, K. G., \& Scott, L. R. (1991) Person, Process, Choice: The Psychology of New 
Venture Creation. Entrepreneurship Theory and Practice, 16, 23-46. https://doi.org/10.1177/104225879201600204

Steven, C., \& Fallows, S. (1998). Enhancing Employability Skills within Higher Education: Impact on Teaching, Learning and Assessment. International Conference on Higher Education Close-Up, Preston, 6-8 July 1998.

Stevenson, H. (1985). A New Paradigm for Entrepreneurial Management. In J. Kao, \& H. Stevenson (Eds.), Entrepreneurship: What It Is and How to Teach It (pp. 30-61). Boston, MA: HBR Press.

Stewart, A. (1991). A Prospectus on the Anthropology of Entrepreneurship. Entrepreneurship Theory \& Practice, 16, 71-92. https://doi.org/10.1177/104225879201600206

The Organisation for Economic Cooperation and Development (OECD) (2001). Science, Technology and Industry Scoreboard. Paris: OECD Publishing.

Zubaidah, A., \& Rugayah, M. (2008). Imperative Attributes for Graduate Employability in Manufacturing Firms: Issues for Internationalizing Malaysia’s Curricula. In Globalisation and Internationalisation of Higher Education in Malaysia (pp. 245-260). Malaysia: Penerbit Universiti Sains Malaysia. 